be possible to obtain with an all-electricity scheme. As to the yearly bill, in I925 it was I8l. xis. for a spacious ten-roomed house, this being divided as follows : coal $4 l$. I4s., coke $3 l$. I6s. $6 d$., gas $6 l$. $5 s .6 d$. electricity $3 l$. I $5 s$. ; well under half the figure quoted by Prof. Parker Smith!

40 Westmount Road,

\section{Gheury de Bray.}

Eltham Park, London, S.E.

Parthenogenesis in Methoca ichneumonides Latr.

IT is well known to collectors of Hymenoptera that the males of the Thynnid, Methoca ichneumonides Latr., are extremely rare, whereas the females are sometimes relatively abundant. Neither sex is common and the insect is described by Sharp as "very rare." It has been suggested that the males have been overlooked by collectors, that their life was short, and that their scarcity was only apparent. Recently I have been able to rear these insects in captivity, and my experiments show clearly that parthenogenesis does occur, a fact which readily explains the scarcity of the males.

In July I924 I caught a number of females of this species near Woking and a single male at Oxshott. These females were provided with Cicindela larvæ, which they stung so as to paralyse them, and on which they afterwards oviposited in the usual way. From the eggs laid by these females a single female emerged in July of the following year. This female was provided with Cicindela larvæ and she was seen to oviposit, although she had never had access to a male. In October I925 I observed that five Methoca cocoons had developed from the ovipositions of this virgin female.

Although I was unable to observe any eggs on the Cicindela larvæ after oviposition by this female, owing to the position of the larvæ in their burrows, there can be no doubt that the cocoons were derived from the eggs laid by this female, and not from eggs laid on the larvæ before their capture. The Cicindela larvæ which I provided for the oviposition were all healthy, lively specimens, taken from open burrows, whereas it is well known that larvæ which have been parasitised by Methoca are very lethargic and incapable of co-ordinated movements of their appendages, the last pair of legs being totally paralysed. After oviposition the Methoca closes the mouth of the burrow of the larvæ, but all the larva I provided were taken only from open burrows.

It will be July 1926 before these cocoons produce imagines, when I hope to be able to decide the sex of the inmates. I have opened one cocoon and found the inmate to be still in the larval condition. I hope to carry out further breeding experiments next year and to obtain sufficient material for cytological work.

So far as I am aware this is the first recorded instance of parthenogenesis in the solitary Vespoidea.

Christ's College, Cambridge, H. T. PAGDEN. January 13 .

The Geological Congress and Museums.

The Compte rendu of the Geological Congress held in Belgium in 1922 has just been received at the British Museum (Natural History). From it I learn that there were made in the rules of organisation, previously formulated in London, certain changes that call for comment. An attempt, possibly unintentional, seems to have been made to restrict the invitations and the list of those competent to serve on the council to purely professional geologists representing official surveys. But this was exposed and defeated by the restoration of at least the universities and geological societies to the list. Museums, however, were quite definitely in so many words eliminated from official representation. I beg to raise, and I hope to lead, an energetic protest against this slur on establishments that are a powerful means of promoting geology. Setting aside the Geological and Mineralogical Departments of the British Museum, which in the past have numbered men of rare and world-wide distinction among their officers, I may instance the American Museum of Natural History, the president of which is this year the recipient of the highest honour that the Geological Society of London can bestow, and the geologists and palæontologists of which have of late thrown light not merely on the past history of the Americas but of the Mongolian Desert.

Museums qua museums are, let us admit, no more deserving than certain bodies which bear the name of "University" or of "Geological Society." But every geologist will agree that there are many among them doing admirable work for his science. I am astonished that this indignity should have been proposed and supported by my friends E. de Margerie and R. W. Brock, men not wholly unfamiliar with the work of museums.

Perhaps I may explain that the personal question does not enter into this protest, since I can, in another capacity, take a seat on the council.

Circumstances no doubt conspired to render the Brussels Congress less representative of the geologists of the world than it might have been. We may, therefore, hope that this question will be taken up again at the International Geological Congress to be held at Madrid during the last week of May, and that on future occasions an official welcome will again be extended to delegates from the leading museums.

F. A. BATHER.

Department of Geology and Palæontology, British Museum (Natural History).

\section{Cirrus at a Lower Level than Alto-cumulus.}

ON Sunday, January 24, at about o9.15, the sky was nearly covered with a sheet of alto-cumulus; this had a straight edge, there being quite clear sky low down in the east. In the northern and western parts of the sky and up to the zenith there were numerous streaks of cirrus uncinus, that is, cirrus streaks with the ends upturned; these were without a doubt below the alto-cumulus. All the clouds were moving from about north-west; the apparent motion of the cirrus was faster than that of the alto-cumulus. The upturned ends of the cirrus were to the southward, the streaks trailing away to the northward. The cirrus appeared dark against the clouds above it. The height of the alto-cumulus was measured with a range-finder. Three separate observations were made on different patches of cloud, at angular altitudes of $30^{\circ}, 22^{\circ}$, and $20^{\circ}$; the heights obtained were I0, $500 \mathrm{ft}$., Io, $140 \mathrm{ft}$., and $10,260 \mathrm{ft}$. These are in very fair accordance, and there is, therefore, not much doubt that the height of the alto-cumulus sheet was between I0,000 and 10,500 feet; the cirrus must, therefore, have been lower, but how much lower it is impossible to say. The best development of the cirrus was at the time I have named, but some cirrus was seen below the alto-cumulus until about mid-day.

I have long been led to believe that cirrus may occur at a very much lower level than that usually given in text-books on meteorology, but I have never before come across such a very definite case.

Stoner Hill, C. J. P. Cave.

Petersfield.

NO. 2936, VOL. II 7 ] 